\title{
Do Public Relations Professionals understand corporate governance issues well enough to advise companies on stakeholder relationship management to ensure organizational sustainability?
}

\author{
Corné Meintjes and Anské F. Grobler \\ Communication Management Division, Department of Business Management, University of
} Pretoria

\begin{abstract}
The King Reports on Governance for South Africa are internationally respected for proposing integrated reporting in a triple bottom-line business context to improve corporate governance. The most recent report, King III, views stakeholder relationship management as a key tenet of corporate governance. The question that begs answering is whether Public relations professionals (PRPs) understand the principles of corporate governance well-enough to inform and guide organizations on the management of stakeholder relationships to ensure organizational sustainability. The views of senior PRPs at selected top performing companies were elicited on their practice of stakeholder relationship management in line with corporate governance principles. It was found that their knowledge on corporate governance was limited, although the importance thereof was recognized; six role functions are fulfilled in managing stakeholder relationships on a strategic or managerial level; these role functions are aligned with the King III principles on stakeholder relationship. The following three were of particular importance: developing corporate strategy, giving advice to senior management and managing crisis communication. Different terminologies were used to build relations with stakeholders and different approaches were used to profile stakeholders. It is recommended that organizations leverage the proven public relations function on strategic and managerial level in support of their corporate governance efforts. In turn, PRPs are encouraged to ensure a deep knowledge on corporate governance issues when counseling senior management on building stakeholder relationships to ensure organizational sustainability.
\end{abstract}

Highlights:

- Senior public relations practitioners' knowledge on corporate governance are limited, but the importance thereof is acknowledged 
- Six role functions are fulfilled in managing stakeholder relationships on a strategic or managerial level

- These role functions are aligned with the King III principles on stakeholder relationship management in support of corporate governance efforts

Key words:

Public relations, stakeholder engagement (SE), governing stakeholder relationships (GSR), stakeholder relationship management (SRM) corporate governance

\section{Introduction}

The alarming increase in financial crises from 11 in the 18th century to 33 in the $20^{\text {th }}$ and an expected 60 in the $21^{\text {st }}$ (Spitzeck \& Hansen, 2010, p. 38) resulted in businesses and governments questioning the way in which companies are managed and how business decisions are made. Managers should have moral and ethical responsibilities to all stakeholders to ensure the long-term sustainability of their business (Sundaram \& Inkpen, 2004, p. 370). The Cadbury Report of 1992 in the United Kingdom and the Sarbaines-Oxley Act of 2002 in the USA are examples of early efforts to point out the importance of corporate governance to curb the occurrence of global financial crises. The King Code of Governance for South Africa 2009 (hereafter referred to as King III) was however probably the first to view stakeholder relationships as a key tenet to ensure good corporate governance. Chapter 8 of the Report entitled 'Governing Stakeholder Relationships' proposes six stakeholder relationship management principles that the Board of Directors should consider in their corporate governance practices.

The success of any organization is inextricably linked to three interdependent sub-systems social, environment and the global economy (Tomorrow's Company, n.d., p. 4). These three systems, commonly referred to as planet, people and profit, should form part of companies' discussions on corporate sustainability (Institute of Directors, 2009, p. 12). This train of thought 
fits well with the strategic constituency perspective as theoretical paradigm in which the current research was conducted. This perspective holds that an organization has a number of stakeholders, each with different degrees of power (Love \& Skitmore, 1996, p. 7) and business success is largely influenced by the extent to which the organization is able to meet these multiple stakeholders' needs and demands. Quinn and Rohrbaugh (1983, p. 364) states that the negative impact of stakeholders can be minimized by identifying the key strategic stakeholders and by understanding and being willing to consider and satisfy their needs and demands.

\section{Research question}

The question that guided the research is whether South African Public Relations Professionals (PRPs) understand corporate governance issues well enough to advise their companies on stakeholder relationship management to ensure organizational sustainability in a triple-bottom context.

\section{The management of stakeholder relationships}

In order to address the research question three terminologies used in the literature to describe the management of stakeholder relationships are presented, followed by a comparative paragraph and table pointing out the differences and the overlaps between them. The six principles on governing stakeholder relationships, as proposed in Chapter 8 of King III are then discussed.

\subsubsection{Stakeholder engagement (SE)}

Stakeholder engagement is defined as the process of involving stakeholders as part of the central business process of transforming organizations to adapt to changing environments. Before stakeholders can become involved, they should be identified and their current levels of 
engagement with the organization should be assessed (Sloan, 2009, p. 26). Corporate leaders are realizing that their stakeholder engagement should become more inclusive by involving different stakeholder groups they should remain committed to the principle of stakeholder inclusion (Sloan, 2009, p. 40).

Different organizations consider stakeholder engagement as a key parameter to indicate socially responsible companies. These organizations include rating agencies, non-profit organizations, standard developing bodies and advocacy organizations from across the globe such as the Ethical Investment Research Services (EIRS) (rating agency), Jantzi Research (rating agency), Innovest Strategic Value Advisors (rating agency), Calvert Investment (ethical investor), Domini Social Investment (ethical investor), AccountAbility (advocacy organization), Global Reporting Initiative (standards organization) and SAM/Dow Jones (stock market indices). These organizations advocate the importance of stakeholder engagement as it is, among other reasons, likely to increase organizational accountability, strengthening the trust, acceptance and credibility of the company (Sloan, 2009:28-29).

\subsubsection{Governing stakeholder relationships (GSR)}

Governing stakeholder relationships, the term used in Chapter 8 of King III to describe the management of stakeholder relationships, seems to be fairly new. "The effective governance of stakeholder relationships is the new global frontier" for communication management (Falconi 2009 , p. 4). He (2009, p. 2) argues that organizations may not necessarily manage their stakeholders, but they govern their relationships with them.

Research conducted by Spitzek and Hansen (2010, p. 378-391) explores how stakeholders are voluntarily granted influence in corporate decision making. The term stakeholder governance is used to describe this process, and power and scope are seen as the two important dimensions. Power is the level of influence given to stakeholders in corporate decision making, while scope is the breadth of power in the decision making process. This implies that there might be stakeholders who do not have a voice in the decision making process in terms of both their 
level and extent of power. Then there may be those stakeholders who do possess extensive power to influence decision-making in the organization (Spitzeck \& Hansen 2010, p. 380). Spitzeck and Hansen (2010, p. 381) developed a stakeholder governance power/scope grid. The following levels of power were identified: (i) no evidence of stakeholder power, (ii) listening to stakeholders' voices, (iii) intermediary impact, (iv) impact on policies and key performance indicators, and ( $v$ ) substantiated impact. The scope of participation depends on the type of issue which will then determine the scope of participation. Issues were classified as operational issues, managerial issues and strategic issues.

\subsubsection{Stakeholder relationship management (SRM)}

"Stakeholder relationships have long been a touchstone of corporate sustainability" (Sloan, 2009 , p. 26) and the management of stakeholder relationships has become a business priority as relationships can create financial, social and environmental sustainability in high-performing organizations (Sloan, 2009, p. 27). Furthermore, businesses are to consider stakeholder inclusion as the norm. Two principles of stakeholder inclusion exist: alignment of values between the organization and stakeholders and dialogue-based empowered relationships. Aligning values entails a devotion to shared points of view and values through discussion and effective communication, as well as a keenness to allow communal values to develop. Dialoguebased empowered relationships are not only aimed at employees, but also at other stakeholders and the focus on two-way communication which enables both employees and other stakeholders to feel encouraged to engage with the organization (Wheeler \& Sillanpää, 1998, p. 204-205). Interaction and discourse with stakeholders should be the responsibility of managers at all levels of the organization and not simply the focus of a specialist department, such as public relations (Phillips, 2004, p. 3).

Steyn and Puth (2000, p. 195) also underscores the importance of stakeholder identification as part of stakeholder relationship management and suggest that research should be undertaken to determine the nature and scope of stakeholders' interests, aspirations, limitations, attitudes, perceptions, hopes and fears and the influence they have on the relationship with the 
organization. Various research approaches are suggested in literature (Falconi, 2009, p. 14; Gregory, 2007, p. 65; Rawlins, 2006, p. 2; Grunig, 2005, p. 778; Steyn \& Puth, 2000, p. 201; Mitchell, Agle \& Wood., 1997, p. 853; Clarkson, 1995, p. 107; Donaldson \& Preston, 1995, p. 66; Freeman, 1984, p. 52; Grunig \& Hunt; 1984, p. 141).

Recognition of risks and opportunities associated with successfully managing company reputation on specifically corporate responsibility issues are increasing globally. Public relations in the $21^{\text {st }}$ century focuses on building relationships with stakeholders through dialogue to improve both organizational reputation as well as the quality of organizational decision-making (corporate responsibility) processes by listening to stakeholders' needs and expectations (Falconi, 2009, p.5). Stakeholders' increased access to significantly more information than in any previous phase of economic development increases their expectations of open communication and information sharing with organizations (Niemann-Struweg, Meintjes \& Grobler, 2007, p. 57). The challenge for organizations is to align stakeholder's information needs with corporate behavior. According to Dawkins (2004, p. 108), stakeholders' information requirements are currently not being met by organizations. Public relations as an organizational business function can be regarded as the 'missing link' in the practice and communication of corporate governance (Dawkins, 2004, p. 108).

\subsection{Discussion of the terminologies in the management of stakeholder relationships}

The focus of stakeholder engagement (SE) is on involving stakeholders, but this does not imply that a relationship is in place. Stakeholder relationship management (SRM) is driven by building and maintaining long-term relationships influenced by power, trust, satisfaction with and commitment to the relationships. Governing stakeholder relationships (GSR) concentrates on the level of influence granted to stakeholders in the organizational decision-making process. It could therefore be concluded that SE is more used to build relationships, whereas the aim of GSR is not on relationship building or maintenance efforts, but it aims to determine the power of stakeholders in decision-making. The intention of SRM is to drive stakeholder inclusion and two-way communication on a more strategic level. 
In short, there seems to be some differences and some overlaps between stakeholder engagement (SE), stakeholder relationship management (SRM) and the governing of stakeholder relationships (GSR). Table 1 reflects an analysis of the terminologies according to the purpose, focus, outcomes, and approaches followed and requirements needed. 
Table 1:Analysis of SE, SRM and GSR

\begin{tabular}{|c|c|c|c|}
\hline & STAKEHOLDER ENGAGEMENT (SE) & $\begin{array}{ll}\text { GOVERNING } & \text { STAKEHOLDER } \\
\text { RELATIONSHIPS (GSR) } & \\
\end{array}$ & $\begin{array}{l}\text { STAKEHOLDER RELATIONSHIP MANAGEMENT } \\
\text { (SRM) }\end{array}$ \\
\hline DEFINITION & Process of involving stakeholders & $\begin{array}{l}\text { Extent to which stakeholders are voluntarily } \\
\text { granted influence in corporate decision- } \\
\text { making }\end{array}$ & Building long-term relationships with key stakeholders \\
\hline PURPOSE & $\begin{array}{l}\text { - } \text { Means to gain acceptance and build } \\
\text { trust of stakeholder } \\
\text { - Drive strategic direction and } \\
\text { operational excellence which leads to } \\
\text { sustainable development }\end{array}$ & $\begin{array}{l}\text { Allowing the influence of stakeholders on } \\
\text { decision-making dependent on the issues at } \\
\text { hand and the relative power of the } \\
\text { stakeholder }\end{array}$ & $\begin{array}{l}\text { Building long-term relationships with key stakeholders } \\
\text { considering six elements: } \\
\text { - Rightful power to influence } \\
\text { - Trust } \\
\text { - Satisfaction with the relationship } \\
\text { - Commitment } \\
\text { - Exchange and communal relationships }\end{array}$ \\
\hline FOCUS & $\begin{array}{l}\text { - Level of policy commitment to } \\
\text { stakeholder } \\
\text { - } \quad \text { Number of engagement activities } \\
\text { - } \quad \text { Focus on performance outcomes }\end{array}$ & $\begin{array}{l}\text { - Power based on evidence of power, } \\
\text { listening to stakeholders' voice, } \\
\text { intermediary impact, impact on } \\
\text { policies and KPIs and substantiated } \\
\text { impact } \\
\text { - Scope based on the type of issues } \\
\text { being operational issues, managerial } \\
\text { issues and strategic issues }\end{array}$ & $\begin{array}{l}\text { - Stakeholder inclusion through dialogue-based } \\
\text { empowered relationships } \\
\text { - Two-way communication }\end{array}$ \\
\hline OUTCOMES & $\begin{array}{l}\text { - } \text { Socially responsible organizations } \\
\text { - Increased accountability } \\
\text { - Strengthened trust and credibility } \\
\text { - Indicator of the quality of } \\
\text { management and long-term financial } \\
\text { performance }\end{array}$ & $\begin{array}{l}\text { - } \quad \text { Improved governance } \\
\text { - } \quad \text { Strengthening of trust and credibility }\end{array}$ & 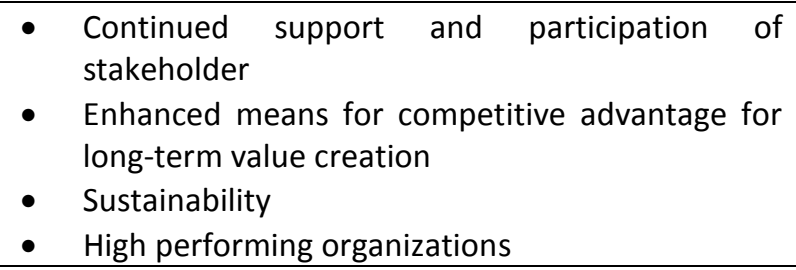 \\
\hline APPROACHES & $\begin{array}{l}\text { AccountAbility's stakeholder engagement } \\
\text { framework }\end{array}$ & $\begin{array}{l}\text { - } \text { GOREL process } \\
\text { - Power/Scope grid of stakeholder } \\
\text { governance } \\
\text { - Clusters of stakeholder governance } \\
\text { mechanisms }\end{array}$ & Inactivity, reactivity, pro-activity and interactivity \\
\hline REQUIREMENTS & $\begin{array}{l}\text { - } \quad \text { Commitment to stakeholder inclusion } \\
\text { by leadership and management } \\
\text { - } \quad \text { Development of a policy }\end{array}$ & None mentioned & $\begin{array}{l}\text { - } \quad \text { Stakeholder inclusion should be the norm } \\
\text { - } \quad \text { Alignment of values }\end{array}$ \\
\hline
\end{tabular}


It would appear that stakeholder relationship management (SRM) is the more encompassing concept as it includes aspects of both stakeholder engagement (SE) and the governing of stakeholder relationships (GSR).

\section{King III Principles on stakeholder relationship management}

The six stakeholder relationship management (SRM) principles, proposed in Chapter 8 of the King III Report are (Institute of Directors, 2009, p. 100-104):

1. The board should appreciate that stakeholders' perceptions affect a company's reputation.

2. The board should delegate to management to proactively deal with stakeholder relationships.

3. The board should strive to achieve the appropriate balance between its various stakeholder groupings, in the best interest of the company.

4. Companies should ensure the equitable treatment of shareholders.

5. Transparent and effective communication with stakeholders is essential for building and maintaining their trust and confidence.

6. The board should ensure disputes are resolved as effectively, efficiently and expeditiously as possible.

These principles hold implications for the roles that senior public relation professionals fulfill in building relations with stakeholder groups to support organizational sustainability in a triplebottom-line business context. The first is PRR's role in making both management and the board of directors of the company aware of how stakeholders view the organization as this has impacts organization reputation directly. However, knowledge on the stakeholders themselves is important to build and maintain relationships and to know how best to communicate with different stakeholder groups. PRP's are in the ideal position to have a deeper understanding of stakeholder interests and expectations, and they can therefore assist the company in aligning company strategy and stakeholder expectations with each other. 
Special mentioning is made in Chapter 8 of the King III Report of shareholders as a specific stakeholder group and how they should be treated. A shareholder is loosely defined as an individual, institution, firm or other entity that owns shares in a company, but according to Henry (2001, p. 226) it is insufficient to capture the people and the relationships involved in shared ownership. Although shareholders can be seen as a stakeholder group, they are distinct from other stakeholder groups as they invest their money to provide risk capital for the company and (in many legal jurisdictions) shareholders' rights are enshrined in law, whereas those in the wider group of stakeholders are not. Shareholders are therefore being privileged over other stakeholders as they are the recipients of the residual free cash flow.

Table 2 provides an overview of the six principles on stakeholder governance in Chapter 8 of the King III Report with short descriptions of the central themes and the key concepts found in each. This is followed by a discussion on the implications of each principle on the practice of public

relations

in

the

organization. 
Table 2: Overview of the King III principles on stakeholder relationship management and their implications on PR

\begin{tabular}{|c|c|c|c|}
\hline KING III PRINCIPLE & CENTRAL THEME & KEY CONCEPTS & IMPLICATIONS ON PR \\
\hline $\begin{array}{lr}\text { The board } & \text { should } \\
\text { appreciate } & \text { that } \\
\text { stakeholders' } & \text { perceptions } \\
\text { affect a } & \text { company's } \\
\text { reputation } & \end{array}$ & $\begin{array}{l}\text { Stakeholders and } \\
\text { reputation }\end{array}$ & $\begin{array}{l}\text { - } \text { Stakeholder/publics } \\
\text { - Stakeholder perceptions } \\
\text { - } \text { Reputation } \\
\text { - Stakeholder interests and } \\
\text { expectations } \\
\text { - Stakeholder inclusive approach } \\
\text { - Stakeholder identification, } \\
\text { classification/categorization and } \\
\text { prioritization } \\
\text { Stakeholder } \\
\text { management }\end{array}$ & $\begin{array}{l}\text { Stakeholder relationship management (SRM) is central to public } \\
\text { relations where SRM includes identification, categorization and } \\
\text { prioritization. Various models and processes exist in the public } \\
\text { relations theory to successfully identify, classify and prioritize } \\
\text { stakeholders and in turn consider their interests and expectations. } \\
\text { This should be approached in a structured and scientific fashion. } \\
\text { This impact reputation. Stakeholder perceptions, which influence } \\
\text { reputation, is central to public relations and the management of } \\
\text { these perceptions a central function of this discipline. }\end{array}$ \\
\hline $\begin{array}{l}\text { The board should delegate } \\
\text { to management to } \\
\text { proactively deal with } \\
\text { stakeholder relationships }\end{array}$ & $\begin{array}{l}\text { Pro-active } \\
\text { management } \\
\text { stakeholder } \\
\text { relationships }\end{array}$ & $\begin{array}{ll}\text { - } & \text { Stakeholder relationship strategy } \\
\text { - } & \text { Constructive engagement } \\
\text { - } & \text { Formal and informal interaction with } \\
\text { - } & \text { stakeholders } \\
\text { - } & \text { Stakeholder responsibilities } \\
\text { - } & \text { Integrated reporting }\end{array}$ & $\begin{array}{l}\text { Public relations may be regarded as a catalyst for pro-active } \\
\text { stakeholder relationship management, and constructive } \\
\text { engagement. Furthermore, public relations have the ability to } \\
\text { formulate a stakeholder relationship strategy, devising formal and } \\
\text { informal interaction platforms to engage with stakeholders. A } \\
\text { policy regarding the handling of sensitive information is } \\
\text { necessary. Finally, public relations, with its role and experience } \\
\text { with annual reports, have an important role to play in the drafting } \\
\text { of the integrated report. }\end{array}$ \\
\hline $\begin{array}{l}\text { The board should strive to } \\
\text { achieve the appropriate } \\
\text { balance between its various } \\
\text { stakeholder groupings, in } \\
\text { the best interest of the } \\
\text { company }\end{array}$ & $\begin{array}{l}\text { Stakeholder } \\
\text { engagement }\end{array}$ & $\begin{array}{ll}\text { - } & \text { Company accountability } \\
\text { - } & \text { Stakeholder responsibilities } \\
\text { - } & \text { Stakeholder engagement strategy }\end{array}$ & $\begin{array}{l}\text { Stakeholder engagement is the practices that are undertaken by } \\
\text { an organization to involve stakeholders in a positive way in the } \\
\text { activities of the organization. For this to happen, a relationship } \\
\text { needs to exist between the organization and its stakeholders } \\
\text { based on trust. This trust in turn is achieved through honest and } \\
\text { open communication addressed in the next principles through } \\
\text { transparent and effective communication. In this context } \\
\text { stakeholder are able to have can understand of what the } \\
\text { organization is accountable for as well as what their } \\
\text { responsibilities as stakeholders are i.e. mutual understanding. }\end{array}$ \\
\hline
\end{tabular}


Table 2: Overview of the King III principles on stakeholder relationship management and their implications on PR

\begin{tabular}{|c|c|c|c|}
\hline KING III PRINCIPLE & CENTRAL THEME & KEY CONCEPTS & IMPLICATIONS FOR PR \\
\hline $\begin{array}{l}\text { Companies should ensure } \\
\text { the equitable treatment of } \\
\text { shareholders }\end{array}$ & $\begin{array}{l}\text { The treatment of } \\
\text { shareholders }\end{array}$ & Equitable treatment of shareholders & $\begin{array}{l}\text { Shareholders invest in companies and can thus bring the board of } \\
\text { the company to account for their actions. The stakeholder } \\
\text { inclusive approach does not place the shareholder above any } \\
\text { other stakeholders. However, long-term share value is important } \\
\text { as a determinant of the long-term company value, which will } \\
\text { benefit not only shareholder, but other stakeholders as well. } \\
\text { Thus, engagement with shareholders (minority shareholders as } \\
\text { well) is as important as engagement with stakeholders. }\end{array}$ \\
\hline $\begin{array}{l}\text { Transparent and effective } \\
\text { communication is essential } \\
\text { for building and maintaining } \\
\text { their trust and confidence }\end{array}$ & $\begin{array}{l}\text { Transparent and } \\
\text { effective } \\
\text { communication } \\
\text { with stakeholders }\end{array}$ & $\begin{array}{l}\text { - Dialogue } \\
\text { - } \text { Alignment of expectations } \\
\text { - } \text { Trakeholder trust and confidence } \\
\text { - Information (complete, timely, } \\
\text { relevant, accurate, honest, } \\
\text { accessible) } \\
\text { - Disclosure processes } \\
\text { - Use of language (clear and simple) } \\
\text { - Responsible communication } \\
\text { - } \quad \text { program communication } \\
\text { - Feedback systems } \\
\text { Promotion of Access to Information } \\
\text { Act, } 2000 \text { (reporting of refusals of } \\
\text { requests for information) }\end{array}$ & $\begin{array}{l}\text { Public relations should ensure that its strategy includes a focus on } \\
\text { stakeholder relationship building and engagement with an } \\
\text { emphasis on building trust and confidence. Platforms should be } \\
\text { established to ensure the dialogue takes place between the } \\
\text { organization and its stakeholders, which in turn will provide the } \\
\text { framework within which the organization and stakeholders may } \\
\text { be able to align their values and expectations. The handling of } \\
\text { information and language should be carefully considered as part } \\
\text { of a responsible communication program and where possible, } \\
\text { policies and practical guidelines should support organization-wide } \\
\text { communication. Part of the creation of platforms for transparent } \\
\text { communication and dialogue is clearly identifiable and streamline } \\
\text { feedback mechanisms. Finally, a crisis communication plan should } \\
\text { form part of the public relations strategy to avoid serious damage } \\
\text { to both stakeholder relationships and ultimately organizational } \\
\text { reputation. }\end{array}$ \\
\hline $\begin{array}{l}\text { The board should ensure } \\
\text { disputes are resolved as } \\
\text { effectively, efficiently and } \\
\text { expeditiously as possible }\end{array}$ & $\begin{array}{l}\text { Dispute or conflict } \\
\text { resolution }\end{array}$ & $\begin{array}{ll}\text { - } & \text { Dispute resolution } \\
\text { - } & \text { Conflict resolution }\end{array}$ & $\begin{array}{l}\text { As part of stakeholder identification, categorization/classification } \\
\text { and prioritization, it is possible for the organization to anticipate } \\
\text { conflict situations with certain stakeholders or stakeholder } \\
\text { groups. Collaboration is necessary to assist the organization and } \\
\text { stakeholder to overcome their problems. One of the key roles of } \\
\text { public relations is dispute resolution and well as strategies for } \\
\text { conflict resolution. }\end{array}$ \\
\hline
\end{tabular}


Close scrutiny indicates that the principles mainly revolve around; i) stakeholders and reputation, ii) proactive management of stakeholder relationships, iii) stakeholder engagement, iv) the treatment of shareholders, v) transparent and effective communication, and vi) dispute and conflict resolution.

In order to address the research question on whether senior PRP's understand corporate governance issues well-enough to advise companies on stakeholder relationship management issues to ensure organizational sustainability, the central ideas of the King III Report were explored in relation to both stakeholder relationship management and public relations theory to inform the interview guide.

\section{Research methodology}

\subsection{Research design}

The research approach adopted was qualitative, using in-depth, personal, face-to-face interviews. The interviews were conducted in the Johannesburg/Tswane, Cape Town and surrounding areas and Durban areas. Qualitative data analysis was used by employing the qualitative data analysis Tesch's model (1990, p. 142-145) and the software package, Nvivo. Interviews were recorded by dicta-phone and then transcribed. A reflective diary was simultaneously kept during the interviews to support of the trustworthiness of the data.

\subsection{Sampling design}

Non-probability convenience or purposive sampling was used to select participants from all senior public relations professionals (PRP's) in South African companies as the population. The selection criteria were that only medium and large sized companies were included; the company's website must make specific reference to corporate governance, corporate citizenship or sustainability; and senior PRPs must be employed on a full-time basis. Participants were identified from the $11^{\text {th }}$ Edition of the Top Performing Companies publication, 
a publication released annually of the top performing companies in SA based on turnover, growth, triple bottom-line, increase in volume of sales, increase in volume of service contracts, capital investment and total value of assets (Fletcher, 2011, p. 7). The six mega cities, better known as metropolitan municipalities, in South Africa are Cape Town, Durban (eThekweni), Ekurhuleni (East Rand), Johannesburg, Nelson Mandela Bay (Port Elizabeth) and Tswane (Pretoria) (South Africa at a glance, n.d., p. 1-2). As most South African companies have their head offices located in either Gauteng (Johannesburg/Tswane), Cape Town and surrounding areas or Durban, these three metropolitan municipalities were used to sample the participants from.

\subsection{Measuring instrument}

The interview guide consisted of five sections: Section A determined the views of PRP's on the role and functions of public relations in their respective organizations; Sections B and C focused on the opinions of PRP's with regard to corporate governance, stakeholder relationships, reputation and conflict resolution or crisis management as the key focus areas derived from the principles on stakeholder relationship management in King III Report. Section D determined PRPs opinions on the implications that the King Report has on the practice of public relations; the role and contribution of PR to organizational success and sustainability; and finally, section $E$, concentrated on the requirements for success for PR in the organization.

\subsection{Pilot testing}

A pilot interview to investigate the feasibility of the planned research and to bring possible deficiencies in the measurement and procedure to the fore (Huysamen, 1993, p. 205) was conducted with the communication specialist at Anglo Platinum (now rebranded as forming part of Anglo American) as the company met the sampling criteria. The interview was recorded by dictaphone, which proved useful as it allowed the opportunity to keep a reflective diary on each question in the interview guide. The interview lasted one hour as initially anticipated and was followed by a debriefing session of 15 minutes. The purpose of the latter was to discuss the appropriateness and applicability of the questions; the comprehension of the wording and 
language used; and if the interviewee was of the opinion that persons in similar positions would be able to answer the questions. Unclear questions were reformulated and redundant questions were removed, while new questions were added.

\subsection{Analysis of results}

The software program Nvivo 9 was used to gather and label the text into categories. This software program allows for the coding of the text into nodes (themes) as each piece of raw data is worked-through. Once the data was coded, the themes were sorted into categories and relationships were identified where possible. This process complied with the requirement that qualitative data analysis should consists of an ongoing process of continual reflection, asking analytical questions, writing memos or keeping and reflective diary and making interpretations (Cresswell, 2009, p. 184).

\section{Discussion of results}

\subsection{Firmagraphic profile}

Companies from various sectors and industries were represented in the research. Table 3 indicates that six of the top performing companies were listed on the JSE (Johannesburg Securities Exchange) Social Responsibility Index.

Table 3: $\quad$ Firmagraphic details of participating companies

\begin{tabular}{|l|l|l|l|}
\hline Name & Size & Industry & SRI index \\
\hline Participant 1 & Large & Wireless Telecom Services & Yes \\
\hline Participant 2 & Large & Real Estate Holding \& Development & Yes \\
\hline Participant 3 & Medium & Household appliances and consumer electronics & No \\
\hline Participant 4 & Medium & Beverages - Distillers \& Vintners & No \\
\hline Participant 5 & Large & Broad line Retailers & Yes \\
\hline Participant 6 & Medium & Hospital Management \& Long-Term Care & Yes \\
\hline Participant 7 & Large & Paper & Yes \\
\hline Participant 8 & Medium & Building \& Construction materials & Yes \\
\hline
\end{tabular}




\begin{tabular}{|l|l|l|l|}
\hline Participant 9 & Large & Specialty and other finance: Accounting and consulting & No \\
\hline
\end{tabular}

\subsection{Senior public relations professionals' views on $P R$}

PR was generally defined as the management (which included messages and channels) and facilitation of communication (through leadership communication, communication integration throughout the organization and through providing advice and support), with the use of research (pre- and post-intervention implementation) at various levels of the organization. Public relations efforts were driven by business issues; different approaches were used to identify both internal and external stakeholders; and relationships with stakeholder groups were managed in accordance with business issues, objectives and intent.

The functions mostly performed by South African PRPs were internal communication, media relations and stakeholder engagement/relationship management. Functions of lesser importance were external communication, investor relationships, reputation management (which includes risk communication), and government and community relations. A few functions, not previously noted in literature were mentioned by the interviewees. They were: consumer communication, industry affairs, business and systems development and sustainability communication.

According to the PRPs, stakeholder relationship management has become a strategic function in the practice of public relations in South Africa. The intention of this strategic business function is to include various stakeholder groups (that is an inclusion stakeholder approach) through two-way communication. Stakeholder relationship management (SSRM) should, according to them, ideally be integrated throughout the organization at each organizational level, business unit, functional area and department, as opposed to being mostly contained in the public relations department. It was established that the South African PRPs fulfill six role functions to achieve this integration: i) stakeholder relationship management ii) strategy involvement and development, iii) reputation management, iv) communication advice-giving, v) crisis communication and vi) message and channel management. 
The identification of these PR functional areas is significant as they are closely aligned with the principles outlined in Chapter 8 of the King III Report. Table 4 indicates this alignment. The second column indicates the level at which the public relations function is performed, while the third column outlines a brief description of the functional area. Column four indicates the King III Principle from Chapter 8 of the King III Report on Governance that specifically addresses the functional area of PR. The principles and the central themes and concepts associated with these are delineated in Table 2.

Table 4: $\quad$ Alignment of the six PRP role functions with the principles in King III

\begin{tabular}{|c|c|c|c|}
\hline Role function & Type & Description/discussion & King III Principle \\
\hline $\begin{array}{l}\text { Stakeholder } \\
\text { relationship } \\
\text { management }\end{array}$ & Strategic* & $\begin{array}{l}\text { South African PRPs view stakeholder } \\
\text { relationship management not only as } \\
\text { strategic, but also as a strategic issue } \\
\text { which involves stakeholder engagement, } \\
\text { managing communication with } \\
\text { stakeholders and establishing a } \\
\text { stakeholder communication framework } \\
\text { for the company. }\end{array}$ & $\begin{array}{l}\text { Principle 2: The board } \\
\text { should delegate to } \\
\text { management to proactively } \\
\text { deal with stakeholder } \\
\text { relationships. }\end{array}$ \\
\hline $\begin{array}{l}\text { Strategic involvement } \\
\text { and development }\end{array}$ & Strategic & $\begin{array}{l}\text { This includes improving business value } \\
\text { and cost saving for the business, } \\
\text { assisting in achieving business goals and } \\
\text { developing strategy. It is done by acting } \\
\text { as the conduit for business activities. It } \\
\text { further includes communicating business } \\
\text { strategy and aligning communication } \\
\text { goals with strategic business goals. }\end{array}$ & $\begin{array}{l}\text { Although this role does not } \\
\text { align with a particular } \\
\text { principle of Chapter } 8 \text { of } \\
\text { King III, it strategic nature } \\
\text { indicates its importance to } \\
\text { all the principles. Its focus is } \\
\text { on acting in the best } \\
\text { interest of the business and } \\
\text { to be involved with issues } \\
\text { management which is } \\
\text { central to the purpose of } \\
\text { the King III Report. }\end{array}$ \\
\hline $\begin{array}{l}\text { Reputation } \\
\text { management }\end{array}$ & Managerial** & $\begin{array}{l}\text { Reputation management is viewed as a } \\
\text { managerial role of public relations as it } \\
\text { contributes to business value and } \\
\text { success. It involves growing goodwill } \\
\text { among stakeholders, managing } \\
\text { perceptions and relationships as well as } \\
\text { media management. }\end{array}$ & 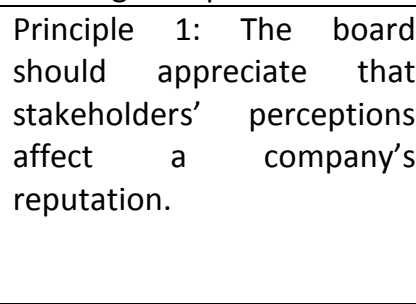 \\
\hline
\end{tabular}




\begin{tabular}{|c|c|c|c|}
\hline $\begin{array}{l}\text { Communication } \\
\text { advise-giving }\end{array}$ & Managerial & $\begin{array}{l}\text { The communication advice-giving role is } \\
\text { also seen as managerial as it consists of } \\
\text { the empowerment of staff in the } \\
\text { business by improving their } \\
\text { communication capability. It also } \\
\text { includes creating awareness of the } \\
\text { communication management function } \\
\text { and the role it plays in the business. }\end{array}$ & All principles \\
\hline Crisis communication & Managerial & $\begin{array}{l}\text { This managerial function includes crisis } \\
\text { avoidance and crisis communication } \\
\text { during crises. Overlap exists with the } \\
\text { reputation management role in terms of } \\
\text { media management as well as the } \\
\text { stakeholder relationship management } \\
\text { role, where, if communication with } \\
\text { stakeholders is managed well, crises may } \\
\text { be avoided. }\end{array}$ & $\begin{array}{l}\text { Principle 6: The board } \\
\text { should ensure disputes are } \\
\text { resolved as effectively, } \\
\text { efficiently and expeditiously } \\
\text { as possible. }\end{array}$ \\
\hline $\begin{array}{l}\text { Message and channel } \\
\text { management }\end{array}$ & Managerial & $\begin{array}{l}\text { This role function is both managerial and } \\
\text { technical in nature and entails } \\
\text { developing communication strategy as } \\
\text { well as the clarification and management } \\
\text { of messages to ensure blockages in } \\
\text { understanding are eliminated. It is } \\
\text { further concerned with identifying key } \\
\text { messages, creating and identifying } \\
\text { channels and managing these channels } \\
\text { and mediums for optimum results. This } \\
\text { is achieved through integration of both } \\
\text { the message and channel. Integrated } \\
\text { communication identified here overlaps } \\
\text { with the theme of integrated } \\
\text { communication identified as part of this } \\
\text { area. }\end{array}$ & $\begin{array}{l}\text { Principle 5: Transparent and } \\
\text { effective communication is } \\
\text { essential for building and } \\
\text { maintaining their trust and } \\
\text { confidence. }\end{array}$ \\
\hline
\end{tabular}

*The strategic role of $P R$ is played at top management level monitoring environmental developments and anticipating consequences (Steyn \& Puth, 2000, p. 20).

**The managerial role is played at the functional, departmental or divisional level of an organisation, developing public relations strategy with an emphasis on message management, problem-solving with a focus on stakeholders (Steyn \& Puth, 2000, p. 20).

\subsection{King III, Chapter 8 focus areas}

Public Relations professionals' understanding of the focus areas of corporate governance, stakeholder relationship management, reputation management and conflict resolution/crisis management as mentioned in Chapter 8 of King III are discussed below. 


\section{Corporate governance}

South African PRPs viewed corporate governance as a result of good corporate leadership. It forms part of strategy development to ensure value for the company and is achieved through the transparency of its actions. Corporate social responsibility (CSR) is seen as part of being a good corporate citizen as outlined by Goodman (2001, p. 118), and not a merely as an activity to meet a legal requirement. South African PRPs were of the opinion that corporate governance and CSR can contribute to the competitiveness and the positive reputation of a company. An opinion not expressed by any of the senior communicators interviewed, was that corporate social responsibility (CSR) forms part of PR as it relates to stakeholder engagement and empowerment (Novelli, 2008, p. 269). The reason for this might be that it was an obvious assumption. The PRPs viewed sustainability as top management's long-term vision, with an added value for both the company and the stakeholders in mind. The preconditions for sustainability were a culture of accountability and ethical conduct. It was mentioned that the unique industry of a particular company should be taken into consideration and issues around what is relevant to the business should be balanced with what is sustainable. The PRPs held a strong opinion that public relations should be integrated into the organizational strategy as it contributes to organizational sustainability. PRPs also took cognizance of the fact that sustainability could give a company a positive value proposition and a competitive edge.

\section{Stakeholder relationship management}

It was found that stakeholder relationship management (SRM) in South African businesses was in some instances practiced proactively and in other reactively. The description of the reactive approach to stakeholder relationship management was similar to that outlined by Steyn and Puth (2000, p. 188), namely waiting for something to happen (stakeholder reaction) and then responding to it. The way in which the PRPs described the proactive approach to SRM aligned however with both the proactive and reactive approach to stakeholder relationship management in literature. The proactive approach involves attempting to predict the behavior of stakeholders and then positioning the organization towards those, while the interactive 
approach has to do with active involvement with stakeholder groups that can affect the future of the organization (Steyn \& Puth, 2000, p. 188).

In most cases stakeholder relationship management was equated with stakeholder engagement. Participants described the process of stakeholder relationship management as a process of profiling their stakeholder. This profiling process, according to participants, consisted of three steps: (i) addressing issues and determining who it impacts upon, (ii) determining what connects the company and the stakeholders, and (iii) conducting issues and/or interest alignment.

The South African senior PRP interviewed did not make mentioning of the concept "governing stakeholder relationships" per se, but most were aware of the extent to which their companies consider the power of different stakeholder groups and the influence it has on corporate decision-making.

When asked how senior PRPs defined their stakeholders, different answers were given. Of concern is that some companies seldom engage in talk or discussions on how they see stakeholders in general. If an organization and its management are unable to define what the concept of stakeholder mean in their context, the identification, engagement and management of stakeholders becomes problematic. The consequence of this is little or no strategic, structured or planned engagement and relationship building initiatives with stakeholders. Those who do define and clearly identify their stakeholders emphasized that the rights of stakeholders are considered, which could be affected by the decisions and behavior of their companies. This aligns closely to the normative view of stakeholders which holds that the value and moral rights of stakeholders are being affected by organizational behavior (Spitzeck \& Hansen, 2010, p. 380).

Although various approaches to stakeholder identification are provided in the literature, only Clarkson's (1995) primary and secondary stakeholder identification approach and Grunig's 
(2005) situational theory of publics approach were used by the PRPs interviewed. One participant delineated an approach not found in the literature. This approach revolve around four C's being client, colleague, channel and community. Some participants mentioned using their intuition to identify stakeholders, while others paid little or no attention to stakeholder identification and thus engagement and relationship building.

Senior PRPs viewed stakeholder engagement as inherent and integrated in their companies. It is mostly seen as a process of identifying and understanding stakeholders, creating platforms for or a means to communicate with them and developing appropriate messaging. Some PRPs have an informal, unstructured approach to stakeholder engagement, while others make use of, what they referred to, as a stakeholder framework. This framework served as a guide to inform who the stakeholders are; which issues affect them; what should be communicated to them; and which methods should be used in communicating to them.

The South African senior PRPs who use a proactive approach to stakeholder relationship management and a have purposeful approach to stakeholder identification, use deliberate communication strategies with the aim of contributing to business effectiveness. Their communication strategies are based on stakeholders, are holistic in nature and provide check points for companies to determine if it is communicating appropriately with its stakeholders. Stakeholder identification and audience segmentation form central elements in the development of the communication strategies impacting the platforms to invest in as well as tailoring specific messages for specific stakeholders.

An area not highlighted by the participants of this study, is the strategic alignment of communication strategy with the strategic goals of the company. Steyn (2007, p. 140) argues that the strategic mandate of PR includes, not only the development of a communication strategy and plans, but also the counseling of business leaders/managers/supervisors on their communication role toward employees, as well as managing their activities and support them. These activities include: (i) developing, implementing and evaluating communication plans in 
support of strategies developed at different business levels, (ii) developing, implementing and evaluating communication plans in support of the strategies of other business functions, and (iii) developing, implementing and evaluating communication plans in support of the top management's communication to employees and other stakeholders.

\section{Reputation management}

PRPs displayed a good understanding of reputation being the sum of the stakeholder perceptions (in the form of the company image) over a period of time. The PRPs interviewed understood reputation management to include issues management and crisis management. Managing stakeholders' perceptions t to the benefit of the company is the core of effective reputation management. The following aspects about a company are considered by the different stakeholder groups in forming an image and ultimately an opinion on its reputation: financial performance; quality of management; social and environmental performance; employee quality and the quality of the goods/services provided. PRPs expressed the opinion that companies should partner with their stakeholders and engage with them through structured conversation in to positively impact their perceptions of the company's reputation.

\section{Conflict resolution/crisis management}

Some confusion seems to exist among the PRPs interviewed regarding the strategies to handling conflict resolution and crisis management, as well as determining who should take responsibility for conflict resolution and crisis communication. In South African businesses, conflict resolution is handled either by the legal department, the risk department, top management, public relations, or a combination of some of these departments. The literature does not stipulate which department should take responsibility for conflict resolution and crisis management. However, Hagan (2007, p. 423-433) stipulate that public relations has a role to play in terms of assisting in understanding the organization's stakeholders, assessing the vulnerabilities of the organization, conducting environmental scanning research and issues management, as well as designating a crisis management team and conducting training activities including mock crisis drills/simulations as part of managing crisis communication. 
The PRPs were clear on their understanding that conflict and crises are caused by unresolved issues and that direct engagement with stakeholders were needed, but they were unsure as to who should drive the conflict resolution process and which steps should be followed in planning a communication strategy and rolling out a crises communication plan. This is particularly significant as managing crisis communication were identified as one of the three particularly important role functions of the South African PRP.

\section{Conclusion}

The King III Report on Governance for South Africa, in particular Chapter 8 on Stakeholder Relationship Management, holds important implications for PRP's not only in South Africa, but also internationally. An understanding of these implications and the important role PRPs have to play in assisting companies with their corporate governance efforts through stakeholder relationship management among PRPs are critical as it requires not only PRPs, but the field of public relations to make the necessary changes to the way in which it is understood and practiced. Currently, South African PRPs realize the importance, but still only have a basic understanding of corporate governance and their role within it. At the same time stakeholder relationship management, in support of corporate governance, are understood and practiced in different ways in South Africa and a more strategic orientation towards stakeholder relationship management is lacking. Part of the problem is that different terminologies are used when talking about the concept of stakeholder relationship management. Associated with this is the use of different approaches to profile stakeholders. PRPs do however fulfill are six functional areas that contribute to improved stakeholder relationship management. The most important of these are developing corporate strategy, giving advice to senior management and managing crisis communication. Top management in organizations does not always realize the potential of a well-devised and well-managed stakeholder relationship and communication strategy in support of corporate strategy. Therefore it is suggested that organizations empower the established public relations function on strategic and managerial level, supporting their 
organizations corporate governance efforts. At the same time a deep comprehension on corporate governance matters among PRPs are advocated when guiding senior management on creating and maintaining stakeholder relationships to safeguard organizational sustainability.

\section{Limitations and suggestion on future research}

The sampling process in the Durban region was challenging. Not many companies met the sampling requirements as they did not have a PR department or in some extreme cases did not practice PR. Suggestions for future research include repeating the research among non-profit organizations, NGO's and government departments in South Africa. Given the global importance of corporate governance to ensure organizational sustainability, repeating the research in other countries may yield interesting results and comparisons between difference world economies could shed light on the importance of public relations in support of corporate governance efforts.

\section{References}

Clarkson, M.B.E. (1995). A stakeholder framework for analyzing and evaluating corporate social performance. The Academy of Management Review, 20(1), 92-117.

Cresswell, J. W. (2009). Research design: qualitative, quantitative and mixed methods approaches. (3rd ed). Thousand Oaks, California: Sage.

Dawkins, J. (2004). Corporate responsibility: the communication challenge. Journal of Communication Management, 9(2), 108-119.

Donaldson, T. \& Preston, L. E. (1995). The stakeholder theory of the corporation: concepts, evidence and implications. Academy of Management Review, 20(1), 65-91.

Falconi, T. (2009). Global Stakeholder relationship governance. [Online] Available from: www.wprf.2010se/.../2010/04/draft-of-Global-stakeholder-Relationship-governance.doc

[Downloaded: 8 September 2011].

Fletcher, R. (2007). Top 500 South Africa's best companies. Cape Town: Topco Media. 
Fletcher, R. (2011). Top performing companies incorporating the public sector. $\left(11^{\text {th }}\right.$ ed). Cape Town: Topco Media.

Freeman, R. E. (1984). Strategic management: a stakeholder approach. Boston: Pitman.

Gregory, A. (2007). Involving stakeholders in developing corporate brands: the communication dimension. Journal of Marketing Management, 23(1), 59-73.

Grunig, J.E. \& Hunt, T. (1984). Managing public relations. New York: Holt, Rinehart \& Winston. Grunig, J. E. (2005). Situational theory of publics. Encyclopedia of Public Relations. Thousand Oaks, CA: Sage (pp. 778-780).

Institute of Directors. (2009). King Report on Governance for South Africa 2009. South Africa: Institute of Directors.

Hagan, L. M. (2007). For reputation's sake: managing crisis communication. In: Toth, E. L. (ed.) The future of excellence in public relations and communication management: challenges for the next generation. Mahwah, New Jersey: Lawrence Erlbaum Associates.

Love, P. E. D. \& Skitmore, M. R. (1996). Approaches to organizational effectiveness and their application to construction organizations. In: Thorpe, A. (ed.) Proceedings 12th Annual Conference and Annual General Meeting, The Association of Researchers in Construction Management, Sheffield Hallam University. [Online] Available from http://eprints.qut.edu.au/archive/00004524 [Downloaded: 21 April 2011].

Mitchel, R.K., Agle, B. R. \& Wood, D. J. (1997). Toward a theory of stakeholder identification and salience: defining the principles of who and what really counts. The Academy of Management Review, 22(4), 853-886.

Niemann-Struweg, I., Meintjes, C., \& Grobler, A.F. (2007). Do South African public relations agencies deliver excellent PR services? A quantitative survey. Communitas, 12, 153-174.

Phillips, D. (2006). Relationships are the core value for organizations: A practitioner perspective. Corporate Communications: An International Journal, 11(1), 34-42.

Rawlins, B. L. (2006). Prioritizing stakeholders for public relations. [Online] Available from: www.instituteforpr.org. [Downloaded: 8 September 2011]. 
Quinn, R. E. \& Rohrbaugh, J. (1983). A spatial model of effectiveness criteria: towards a competing values approach to organizational effectiveness. Journal of Management Science. 29, 363-377.

Sloan, P. (2009). Redefining stakeholder engagement: from control to collaboration. Journal of Corporate Citizenship, Winter, 25-40.

Spitzeck, H. \& Hansen, E. G. (2010). Stakeholder governance: how stakeholders influence corporate decision making. Corporate Governance, 10(4), 378-391.

Steyn, B. \& Puth, G. (2000). Corporate Communication Strategy. Sandton: Heinemann.

Steyn, B. (2007). Contribution of public relations to businessal strategy formulation. In Toth (ed.). The future of excellence in public relations and communication management: challenges for the next generation. Mahwah, NJ: Lawrence Erlbaum Associates.

Sundaram, A. K. \& Inkpen, A. C. (2004). Stakeholder theory and "The Corporate Objective Revisited": a reply. Organization Science, 15(3), 370-371.

Tesch, R. (1990). Qualitative research: analysis types and software tools. New York: Falmer. Tomorrow's company. (n.d) . Tomorrow's global company. [Online] Available from: http://www.tomorrowscompany.com/uploads/TGCexcu.pdf [Downloaded: 14 April 2011].

Wheeler, D. \& Sillanpää, M. (1998). Including the stakeholders: the business case. Long Range Planning, 31(2), 201-210. 